Available online at: http://proceeding.rsfpress.com/index.php/ic-smart/index

Proceeding on International Conference of Science Management Art Research Technology

(IC-SMART)

Volume 1 Number 1 (2020): 64-70

\title{
Designing Assessment Model of Quality Management Maturity in Manufacturing Industry with TQM Approach
}

\author{
Teguh Prabowo, Singgih Saptadi, Purnawan Adi W. \\ Industrial Engineering Department, Faculty of Engineering, Diponegoro University, Semarang, \\ Indonesia \\ E-mail address teguhprabowo21728@gmail.com; E-mail address singgihs@ft.undip.ac.id; E- \\ mail address purnawan@fft.undip.ac.id
}

\begin{abstract}
The design of performance assessment and measurement models is an important factor for any organization in an effort to achieve the expected goals in the future and as a tool to assess the success of the company. One of the most important performance measures is quality management. An assessment model that can be used to measure the performance of quality management is the Quality Management Maturity (QMM) Model. Until now, there has been no research related to the design of the QMM assessment model in the manufacturing industry sector. Until now, research related to the QMM Model only examines the construction industry sector, and the number is still relatively small. Even though, according to the 2020 Statistical Yearbook of Indonesia sources, the industrial sector that provides the largest contribution to Indonesia's national income in 2019 is the manufacturing industry sector. Therefore, the aim of this study is to design a QMM assessment/conceptual model in the manufacturing industry sector by identifying variables related to quality management. In this study, a literature study approach was used by examining ten journals that have a relationship with quality management. The results showed that the QMM model consisted of several levels, each of which was built by a number of quality management variables. Based on the results of the analysis of all available literature, the results of the variables at each level are obtained, namely at level 1 consisting of 2 variables, namely corporate-level quality and project level quality. Whereas at level 2, project quality level variables are divided into two variables, namely product quality and service quality. At level 3, corporatelevel quality is divided into two variables, namely external management and internal management. In addition, at level 3, product quality is divided into two variables, namely physical quality and perceived quality. Meanwhile, at level 4, each variable result from level 3 is further divided into a number of variables. In external management, there are six variables, in internal management, there are 28 variables, seven variables in physical quality, four variables in perceived quality, and 19 variables in service quality.
\end{abstract}

Keywords: Quality Management Maturity Model, Total Quality Management

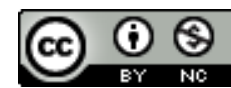

This is an open access article under the CC-BY-NC license 


\section{INTRODUCTION}

The design of performance assessment and measurement models is an important factor for any company or organization. Both of these are used as basic keys to creating organizational planning in an effort to achieve the expected goals in the future and as a tool to assess the success of the company (Pereira \& Oyadomari, 2014). Designing performance appraisal and measurement models is part of project management. One very important part of project management is quality management (Willis, 2012). From the perspective of a manufacturing company, quality management within the company means maintaining the required and standardized quality of company performance so as to obtain customer satisfaction, which will bring long-term competitiveness and business survival for the company. Quality management must provide an environment where related tools, techniques and procedures can be used effectively so as to produce operational success for the company (Xiaofen, 2013).

One of the assessment models that companies can use in measuring the level of quality management is the Quality Management Maturity (QMM) Model (Permatasari, et al., 2017). By using the Quality Management Maturity (QMM) Model, a company can determine the maturity level of the company's quality management. Then the company can find out what aspects of quality management need improvement efforts and provide the right solutions that can improve company performance. Actually, there are a number of studies that use this model to measure the level of quality management in companies, but they are still relatively few, and all of these studies examine construction companies. There are still no studies that use the QMM assessment model in manufacturing companies. Whereas according to the source of the 2020 Statistical Yearbook of Indonesia, Indonesia's national income is based on Gross Domestic Product at Current Prices. According to Business Fields in 2019, the industrial sector that made the largest contribution was the Manufacturing Industry with a GDP of 3,119,617.3 billion rupiahs or amounting to $20.5 \%$ of the total national income. This figure is very far from the construction sector, which only contributed $1,701,741.2$ billion rupiahs or $11.2 \%$ of the total national income (BPS, 2020).

Based on all of the above backgrounds, until now, there has been no research related to the design of the QMM (Quality Management Maturity) assessment/conceptual model in the manufacturing industry sector. Research related to QMM (Quality Management Maturity) Model until now only examines the construction industry sector, and the number is still relatively small. Therefore, the aim of this research is to compile or design a Quality Management Maturity assessment/conceptual model in the manufacturing industry sector. By using the Quality Management Maturity (QMM) Model, the manufacturing industry can make performance measurement efforts related to company quality management. Then the company can find out what aspects of quality management need improvement efforts and provide the right solutions that can improve company performance so that the company can continue to survive and win the competition in the business world.

\section{LITERATURE REVIEW}

\section{IV.1. Performance Appraisal}

Performance is a description of the level of achievement of the implementation of an activity or program or policy in realizing the goals, objectives, mission, and vision of the organization, as stated in the strategic planning of an organization. Performance can be known only if the individual or organization has established success criteria. These success criteria are in the form of certain goals or targets to be achieved (Mahsun, 2006). 
Meanwhile, performance measurement is the process of assessing the progress of work against predetermined goals and objectives. This includes information on several things such as the efficient use of resources in producing goods and services, the quality of goods and services (how well the goods and services are delivered to the customer and to what extent the customer is satisfied), the results of activities compared to the intended purpose, and the effectiveness of actions. in achieving goals (Sardi, et al., 2020).

\section{IV.2. Quality Management}

Sourced from Tjiptono and Chandra (2016), defines quality as dynamic conditions related to products, services, human resources, processes, and the environment that meet or exceed expectations (Tjiptono \& Chandra, 2016). Glodzinski (2018) describes quality as a philosophy and principle that describes continuous organizational improvement (Glodzinski, 2018). Quality can be translated into quality dimensions, which include the level of quality, reliability, and safety, quality performance, durability, and capability in service (Wanberg et al., 2013).

According to Ronnback and Eriksson (2012), quality management is a concept that consists of 3 main things, namely, principles, practices, and techniques. In principle, quality management is a set of underlying assumptions about how the organization views and its relationships with customers, competitors, and suppliers. Whereas in practice, quality management is seen as an activity carried out to display and realize principles, such as collecting customer information and conducting customer surveys. Meanwhile, technically, quality management is seen as a guideline and infrastructure for carrying out certain practices, such as the voice of the customer tables and quality function deployment (Ronnback \& Eriksson, 2012).

\section{IV.3. Quality Management Maturity Model}

According to Wilson (2015), the quality management maturity model brings together various descriptions and definitions related to quality from various existing literature and is further analyzed to design an assessment model. The quality management maturity model describes a quality culture with various principles such as doing something right, doing the right thing, learning, adapting to the business environment, and aiming explicitly and precisely to improve quality. Quality is created by strong leadership and by organizational people whose cultural existence is determined through organizational alignment (Wilson, 2015).

The Project Management Institute has defined five levels or five stages in assessing Quality Management Maturity (PMI, 2013):

1. Level 1: (None) - There is no Quality Management practice in the company.

2. Level 2: (Standardize) - There are little standardization, documentation, and communication in the company organization.

3. Level 3: (Measure) - The standardization process is used in almost all departments in the company, and process measurements are taken to evaluate organizational effectiveness.

4. Level 4: (Control) - Processes that have been measured are corrected again by establishing upper and lower limits and processes that are always analyzed.

5. Level 5: (Improve) - Continuous improvement of processes into practice for best practice standard results.

\section{IV.4. Total Quality Management (TQM)}


Total Quality Management (TQM) is the most central defining method of quality management. TQM is the father of all existing quality management methods and standards such as Six Sigma, CMM, ISO 9000, the Zero Defect movement, Gemba Kaizen for Just-in-Time (Lean) Manufacturing, and so on (Kemp, 2006). Total Quality Management (TQM) is a process approach to improving quality in order to increase organizational competitiveness. TQM is a new paradigm in running a business that seeks to maximize organizational competitiveness through a focus on customer satisfaction, the involvement of all employees, and continuous improvement of the quality of products, services, people, processes, and the organizational environment (Krajewski, et al., 2006).

As an approach, Total Quality Management (TQM) emphasizes various processes within the organization/company in improving the quality of products/services (Gaspersz, 2011). Gaspersz (2011) defines Total Quality Management (TQM) as a way to continuously improve performance at every level of operation or process, within each functional area of an organization, by using all available human resources and capital. One of the best ways in global competition is to produce a product or service of the highest quality. The best quality will be obtained by making continuous efforts to improve human capabilities, processes, and the environment (Gaspersz, 2011).

\section{RESEARCH METHODOLOGY}

In this study, a literature study approach was used by examining 10 journals that have a relationship with Quality Management. In general, of the ten journals used, two of them use the QMM (Quality Management Maturity) model, while the other eight journals use the TQM (Total Quality Management) approach. Because there are only two literary journals that use the QMM Model and both journals are in the context of construction companies, other journals that discuss quality management in manufacturing companies are needed. Because the study in this research is in the context of a manufacturing company. And to obtain quality management related variables that are suitable for use in building QMM models in manufacturing companies, the researchers used eight other journals that discuss Total Quality Management. Each journal that is used as the basis for this research also has different object problems, models, variables, methods, and results. The results of the analysis from various literature will then be used in designing the QMM (Quality Management Maturity) model.

\section{FINDING AND DISCUSSION}

The QMM (Quality Management Maturity) model consists of several levels, where each level is built by various quality management variables. This study resulted in the identification of quality management variables at each level and the design of the QMM (Quality Management Maturity) model based on all the variables that have been obtained.

\section{IV.5. QMM Variables}

Based on the results of the analysis of all existing literature, the following are the results of the variables for each level, namely at level 1 consisting of 2 variables, namely corporate-level quality and project quality level. Whereas at level 2 , project quality level variables are divided into two variables, namely product quality and service quality. At level 3, corporate-level quality is divided into two variables, namely external management and internal management. In addition, at level 3, product quality is divided into two variables, namely physical quality and perceived quality. Meanwhile, at level 4, each variable result from level 3 is further divided into a number of variables. In external management, six variables are obtained, including People \& Customer Management / Involvement, Supplier Partnership / Supplier Relations / Supplier Development, Communication of 
Improvement Information, Customer Satisfaction Orientation, External Interface Management, and Impact on Society.

Whereas in internal management, 28 variables were obtained, including Strategic Quality Management / Policy and Strategic Planning, Team Work Structures for Improvement, Operational Quality Planning, Quality Improvement System, Corporate Quality Culture, Quality Data, and Reporting, Technology Management, Research and Development, Top Management Commitment, Employees Empowerment / Encouragement / Involvement / Participation, Training and Education, Teamwork / Respect for People, Top Management Support / Leadership, Training and Education, Reward and Recognition, Vision and Mission Statement, Process Control Improvement, Process Improvement / Management, Outcome Orientation, Stability, Aggressiveness, Inventory Management, Continuous Improvement and Innovation, Information Analysis, Human Resource Management, Strategic Planning, Coordination Between Departments, Improvement Product Design, People Management / People Satisfaction.

In Physical Quality, there are seven variables, namely Performance, Features, Reliability, Conformance, Product Innovation, Product Design, Attention to detail. Perceived Quality obtained four variables, namely Durability, Serviceability, Aesthetics, and Perceived Quality. Meanwhile, Service Quality obtained 19 variables, namely Service Reliability, Responsiveness, Assurance, Empathy, Tangibles, Time, Timeliness, Completeness, Courtesy, Consistency, Accessibility \& Convenience, Accuracy, Communication, Credibility, Security, Competence, Understanding, Recovery, Customer. Focus / Customer Satisfaction / Customer Feedback.

\section{IV.6. Designing the QMM (Quality Management Maturity) Model}

By using the results of the analysis of all the variables above, the results are obtained from the QMM model design:

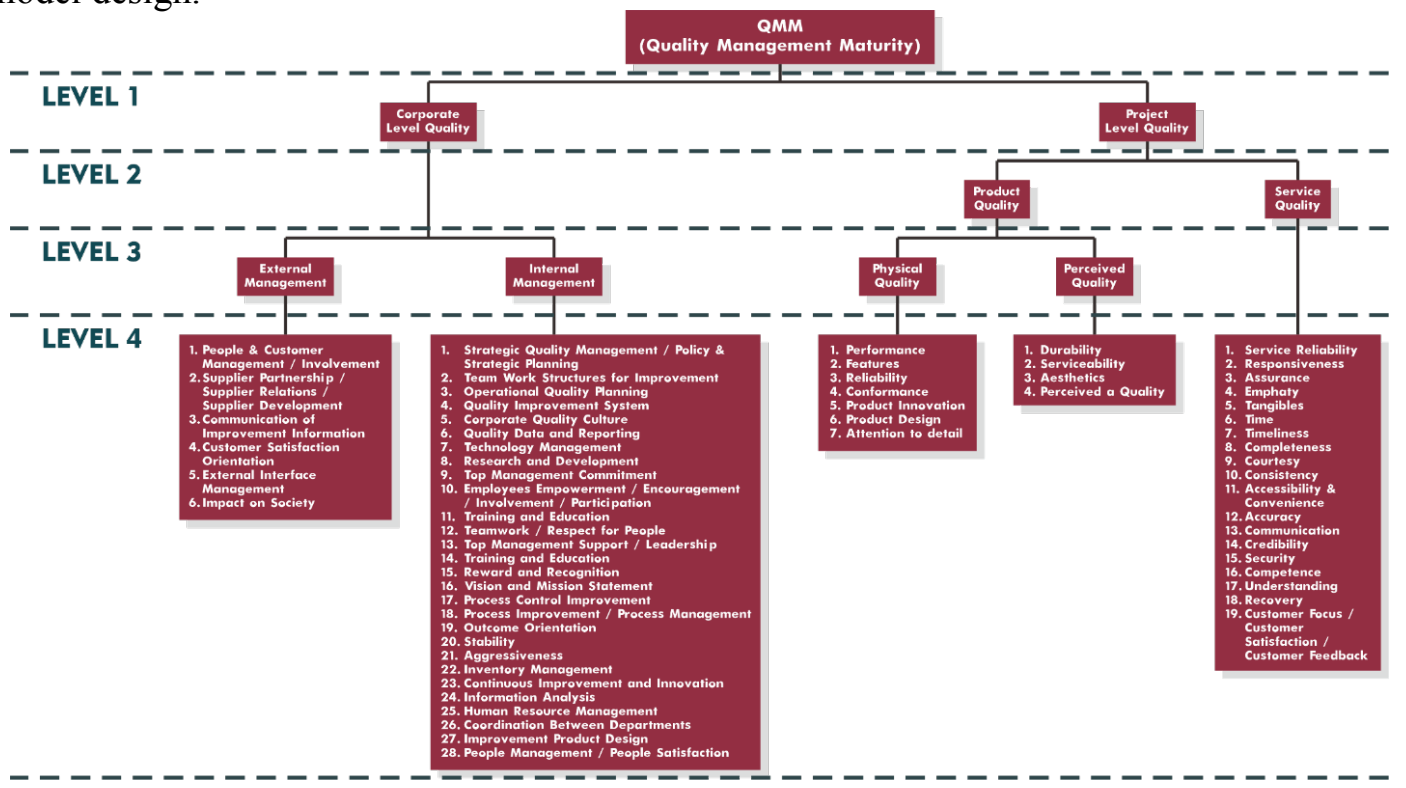

Figure 1. Result of Quality Management Maturity Model

\section{CONCLUSION AND FURTHER RESEARCH}

The aim of this research is to compile or design a Quality Management Maturity assessment model in the manufacturing industry sector. By using the Quality Management Maturity (QMM) Model, the manufacturing industry can make performance measurement efforts related to company quality management. Then the company can find out what aspects of quality management need improvement 
efforts and provide the right solutions that can improve company performance so that the company can continue to survive and win the competition in the business world.

In this study, a literature study approach was used by examining ten journals that have a relationship with Quality Management. Of all these journals, there are only two literary journals that use the QMM Model, and both journals are in the context of a construction company, so other journals are

needed that discuss quality management in manufacturing companies. Because the study in this research is in the context of a manufacturing company. And to obtain quality management related variables that are suitable for use in building QMM models in manufacturing companies, the researchers used eight other journals that discuss Total Quality Management.

The resulting design of the QMM (Quality Management Maturity) model consists of several levels, each of which is built by a number of quality management variables. Based on the results of the analysis of the entire literature available, the results of the variables for each level are obtained, namely at level 1 consisting of 2 variables, namely corporate-level quality and project quality level. Whereas at level 2, project quality level variables are divided into two variables, namely product quality and service quality. At level 3 , corporate-level quality is divided into two variables, namely external management and internal management. In addition, at level 3, product quality is divided into two variables, namely physical quality and perceived quality. Meanwhile, at level 4, each variable result from level 3 is further divided into a number of variables. In external management, there are six variables, in internal management, there are 28 variables, seven variables in physical quality, 4 variables in perceived quality, and 19 variables in service quality. In the future, researchers hope that there will be further studies or research related to the use of this designed QMM model to measure aspects of quality management in manufacturing companies. So that companies can find out what aspects of quality management need improvement efforts and provide the right solutions that can improve company performance so that the company can continue to survive and win the competition in the business world.

\section{REFERENCES}

Ahmed, A. O. \& Idris, A. A., 2020. Examining the relationship between soft total quality management (TQM) aspects and employees' job satisfaction in "ISO 9001" Sudanese oil companies. The TQM Journal, pp. 1754-2731.

Baird, K., Hu, K. J. \& Reeve, R., 2011. The Relationships between Organizational Culture, Total Quality Management Practices and Operational Performance. International Journal of Operations \& Production Management, pp. 789-814.

Belay, A. M. et al., 2014. Adoption of Quality Management Practices An Investigation of its Relationship with Labor Productivity for Labor-Intensive Manufacturing Companies. Benchmarking: An International Journal, pp. 77-100.

BPS, 2020. Statistical Yearbook of Indonesia 2020. 1nd ed. Jakarta: BPS-Statistics Indonesia.

Gaspersz, V., 2011. Total Quality Management. Jakarta: PT Gramedia Pustaka Umum.

Glodzinski, E., 2018. Project Assessment Framework: Multidimensional Efficiency Approach Applicable for Project-Driven Organizations. Warsaw, Elsevier Ltd, p. 731-738.

Habtoor, N., 2016. Influence of Human Factors on Organisational Performance. International Journal of Productivity and Performance Management, pp. 460-484.

Idrus, A. B. \& Sodangi, M., 2010. Framework for Evaluating Quality Performance of Contractors in Nigeria. International Journal of Civil \& Environmental Engineering, pp. 31-36.

Kemp, S., 2006. Quality Management Demistified. New York: McGraw-Hill.

Knowles, G., 2011. Quality Management. Woburn: bookboon.com.

Krajewski, L. J., Ritzman, L. P. \& Malhotra, M. K., 2006. Operations Management: Processes and Value Chains, 8th edition. Indiana: Prentice Hall. 
Mahsun, M., 2006. Pengukuran Kinerja Sektor Publik. Yogyakarta: Penerbit BPFE.

Modgil, S. \& Sharma, S., 2016. Total Productive Maintenance, Total Quality Management and Operational Performance. Journal of Quality in Maintenance, pp. 353-377.

Okrah, E. B. \& Fening, F. A., 2012. TQM Implementation: a Case of a Mining Company in Ghana. Benchmarking: An International Journal, pp. 743-759.

Pereira, D. D. S. \& Oyadomari, J. C. T., 2014. Performance Measurement System and Quality Management in Small and Medium-Sized Brazilian Enterprises. Accounting in Emerging Economies, pp. 151-184.

Permatasari, F. L., Adi, T. J. W. \& Wiguna, I. P. A., 2017. Assessment Model of Contractor Quality Management Maturity. Surabaya, The Third International Conference on Civil Engineering Research (ICCER), pp. 382-390.

PMI, 2013. A Guide to the Project Management Body of Knowledge. Pennsylvania: Project Management Institute.

Ronnback, A. \& Eriksson, H., 2012. A Case Study on Quality Management and Digital Innovation. International Journal of Quality and Service Sciences, pp. 408-422.

Sardi, A., Sorano, E., Garengo, P. \& Ferraris, A., 2020. The Role of HRM in the Innovation of Performance Measurement and Management Systems: a Multiple Case Study in SMEs. Employee Relations: The International Journal, pp. 101-118.

Singh, R. K., 2011. Analyzing the Interaction of Factors for Success of Total Quality Management in SMEs. Asian Journal on Quality, pp. 6-19.

Talib, F., Rahman, Z. \& Q., 2013. An Empirical Investigation of Relationship between Total Quality Management Practices and Quality Performance in Indian Service Companies. International Journal of Quality \& Reliability Management, pp. 280-318.

Tjiptono, F. \& Chandra, G., 2016. Service, Quality \& Satisfaction. Yogyakarta: Penerbit Andi.

Wanberg, J., Harper, C., Hallowell, M. R. \& Rajendran, S., 2013. Relationship between Construction Safety and Quality Performance. Journal of Construction Engineering and Management, pp. 401-411.

Willis, C. J., 2012. The Construction Industry Macro Maturity Model (CIM3): Theoretical Underpinnings. International Journal of Productivity and Performance Management, pp. 382-402.

Wilson, F., 2015. The Quality Maturity Model: Your Roadmap to a Culture of Quality. New York, New York University, p. Vol 36.

Xiaofen, T., 2013. Investigation on Quality Management Maturity of Shanghai Enterprises. The TQM Journal, pp. 417-430. 